\title{
Development of Molecular Markers for Predicting Radish (Raphanus sativus) Flesh Color Based on Polymorphisms in the RsTT8 Gene
}

\author{
Soyun Kim ${ }^{1}$, Keunho Yun ${ }^{1}$, Han Yong Park ${ }^{2}$, Ju Young Ahn ${ }^{1}$, Ju Yeon Yang ${ }^{1}$, Hayoung Song ${ }^{1}$, O New Lee ${ }^{2} \mathbb{D}$, \\ Yoonkang Hur ${ }^{1, *}$ and Man-Ho Oh ${ }^{1, *(1)}$
}

1 Department of Biological Sciences, Chungnam National University, Daejeon 34134, Korea; soyun9096@naver.com (S.K.); keunho0307@gmail.com (K.Y.); wnduds357@naver.com (J.Y.A.); sjss508@naver.com (J.Y.Y.); hayoung282@hanmail.net (H.S.)

2 College of Life Sciences, Sejong University, Seoul 05006, Korea; hypark@sejong.ac.kr (H.Y.P.); onewlee@sejong.ac.kr (O.N.L.)

* $\quad$ Correspondence: ykhur@cnu.ac.kr (Y.H.); manhooh@cnu.ac.kr (M.-H.O.); Tel.: +82-42-821-6279 (Y.H.); +82-42-821-5497 (M.-H.O.)

check for updates

Citation: Kim, S.; Yun, K.; Park, H.Y.; Ahn, J.Y.; Yang, J.Y.; Song, H.; Lee, O.N.; Hur, Y.; Oh, M.-H.

Development of Molecular Markers for Predicting Radish (Raphanus sativus) Flesh Color Based on Polymorphisms in the RsTT8 Gene. Plants 2021, 10, 1386. https:/ / doi.org/10.3390/plants10071386

Academic Editor: Massimo Galbiati

Received: 6 June 2021

Accepted: 3 July 2021

Published: 6 July 2021

Publisher's Note: MDPI stays neutral with regard to jurisdictional claims in published maps and institutional affiliations.

Copyright: (C) 2021 by the authors. Licensee MDPI, Basel, Switzerland. This article is an open access article distributed under the terms and conditions of the Creative Commons Attribution (CC BY) license (https:/ / creativecommons.org/licenses/by/ $4.0 /)$.

\begin{abstract}
Red radish (Raphanus sativus L.) cultivars are a rich source of health-promoting anthocyanins and are considered a potential source of natural colorants used in the cosmetic industry. However, the development of red radish cultivars via conventional breeding is very difficult, given the unusual inheritance of the anthocyanin accumulation trait in radishes. Therefore, molecular markers linked with radish color are needed to facilitate radish breeding. Here, we characterized the RsTT8 gene isolated from four radish genotypes with different skin and flesh colors. Sequence analysis of RsTT8 revealed a large number of polymorphisms, including insertion/deletions (InDels), single nucleotide polymorphisms (SNPs), and simple sequence repeats (SSRs), between the red-fleshed and white-fleshed radish cultivars. To develop molecular markers on the basis of these polymorphisms for discriminating between radish genotypes with different colored flesh tissues, we designed four primer sets specific to the RsTT8 promoter, InDel, SSR, and WD40/acidic domain (WD/AD), and tested these primers on a diverse collection of radish lines. Except for the SSR-specific primer set, all primer sets successfully discriminated between red-fleshed and white-fleshed radish lines. Thus, we developed three molecular markers that can be efficiently used for breeding red-fleshed radish cultivars.
\end{abstract}

Keywords: RsTT8; InDels; SNPs; flesh color; molecular marker

\section{Introduction}

Radish (Raphanus sativus L.; Brassicaceae) is an economically important root vegetable cultivated worldwide for its edible taproots, sprouts, and seed oil. Taproots of radish contain dietary fiber, carbohydrates, and essential minerals and nutrients that benefit human health [1]. In addition, red radishes contain significant amounts of anthocyanins, phenolics, and flavonoids, which contribute substantially to their antioxidant activity [1-3]. Radish taproots typically display four types of color patterns: red skin with red flesh (RsRf), green skin with red flesh (GsRf), red skin with white flesh (RsWf), and white skin with white flesh (WsWf).

One of the radish breeding targets over the past three decades has been the development of red radish cultivars with improved functionality [4,5]. Red radish cultivars are a potential source of natural colorants, as they are rich in anthocyanins, which are highly stable and highly similar to the artificial pigment, Food Red No. 40 [6,7]. Among the six types of anthocyanins, pelargonidin-based anthocyanins are mainly found in red radishes, which enable their differentiation from other radishes containing cyanidin- or delphinidin-based anthocyanins [1,8-11]. 
Anthocyanin is synthesized via the flavonoid pathway by two groups of genes: early biosynthesis genes (EBGs) and late biosynthesis genes (LBGs)[12,13]. The EBG group consists of chalcone synthase $(\mathrm{CHS})$, chalcone isomerase $(\mathrm{CHI})$, flavanone 3-hydroxylase $(\mathrm{F} 3 \mathrm{H})$, flavanone $3^{\prime}$-hydroxylase $\left(F 3^{\prime} H\right)$, and flavonol synthase $(F L S)$ [14-17]; whereas, the LBGs include dihydroflavonol 4-reductase (DFR), leucoanthocyanidin oxygenase/anthocyanidin synthase (LDOX/ANS), anthocyanidin reductase (ANR), and UDP-glucose: flavonoid 3O-glucosyltransferase (UD3GT), which are activated by the MYB-bHLH-WD40 (MBW) complex [12,17-19]. The MBW complex is composed of an R2R3-type MYB transcription factor MYB123 (encoded by TRANSPARENT TESTA 2 [TT2]), a basic helix-loop-helix (bHLH) protein bHLH042 (encoded by TT8), and a WD40 repeat (WDR)-containing protein (encoded by TRANSPARENT TESTA GLABRA 1 [TTG1]).

The bHLH proteins comprise a large class of transcription factors divided into $26 \mathrm{sub}-$ groups [20]. Flavonoid-related bHLH proteins, which cluster into subgroup IIIf, contain an MYB-interaction region (MIR) at the N-terminus, followed by a WDR-interacting region (WD), an acidic domain (AD), a bHLH domain, and the C-terminal region; which together mediate the homo- or heterodimerization of bHLH proteins [21,22]. Thus, bHLH transcription factors, together with R2R3 MYB proteins, play a crucial role in anthocyanin biosynthesis in plants.

Several flavonoid-related $b H L H$ genes have been identified in plants: GLABRA3 (GL3) [23-28], ENHANCER OF GLABRA3 (EGL3) [24-26], MYC1 [29,30], and TT8 [25,28,31,32]. Each bHLH gene is involved in the regulation of two or more traits in a partially redundant manner. The RsTT8 gene was recently isolated and characterized [33], and its role in anthocyanin accumulation is supported by genomic and transcriptomic studies. The defective expression of TT8 caused by either transposable element (TE) insertion or mutation has been shown to affect anthocyanin accumulation in Brassica species, including B. rapa [34], B. juncea [35], and B. oleracea [36]. In radish, although the upregulation of RsTT8 expression has been associated with red skin or red flesh [33,37], polymorphisms in RsTT8 associated with radish skin or flesh color have not yet been identified.

In this study, we isolated the RsTT8 gene from four radish genotypes with different colored skin and flesh tissues and detected several polymorphisms (insertion/deletion mutations [InDels], single nucleotide polymorphisms [SNPs], and simple sequence repeats [SSRs]) between red-fleshed and white-fleshed accessions. The four radish genotypes showed no differences in RsTT8 promoter activity; however, the expression level of RsTT8 correlated with flesh color. Therefore, we developed and validated PCR-based molecular markers based on these polymorphisms to distinguish between radish accessions with different colored flesh. These markers could be efficiently applied to radish breeding for the development of red-fleshed radish cultivars.

\section{Results}

\subsection{Selection of Radish Inbred Lines with Different Taproot Coloration}

Radish inbred lines with different taproot skin and flesh colors (RsRf, GsRf, RsWf, and WsWf) were used in this study (Figure 1). The anthocyanin content of skin and flesh of each inbred line was measured just after the hypocotyl skin peeled off (ca. 35 days post-germination) (the skin of GsRf still exhibited anthocyanin accumulation) (Figure 1A). The coloration of the flesh was most distinct at the time of harvest, and the skin color of the RsRf inbred line used in this study was not as red as seen in other RsRf radishes. 


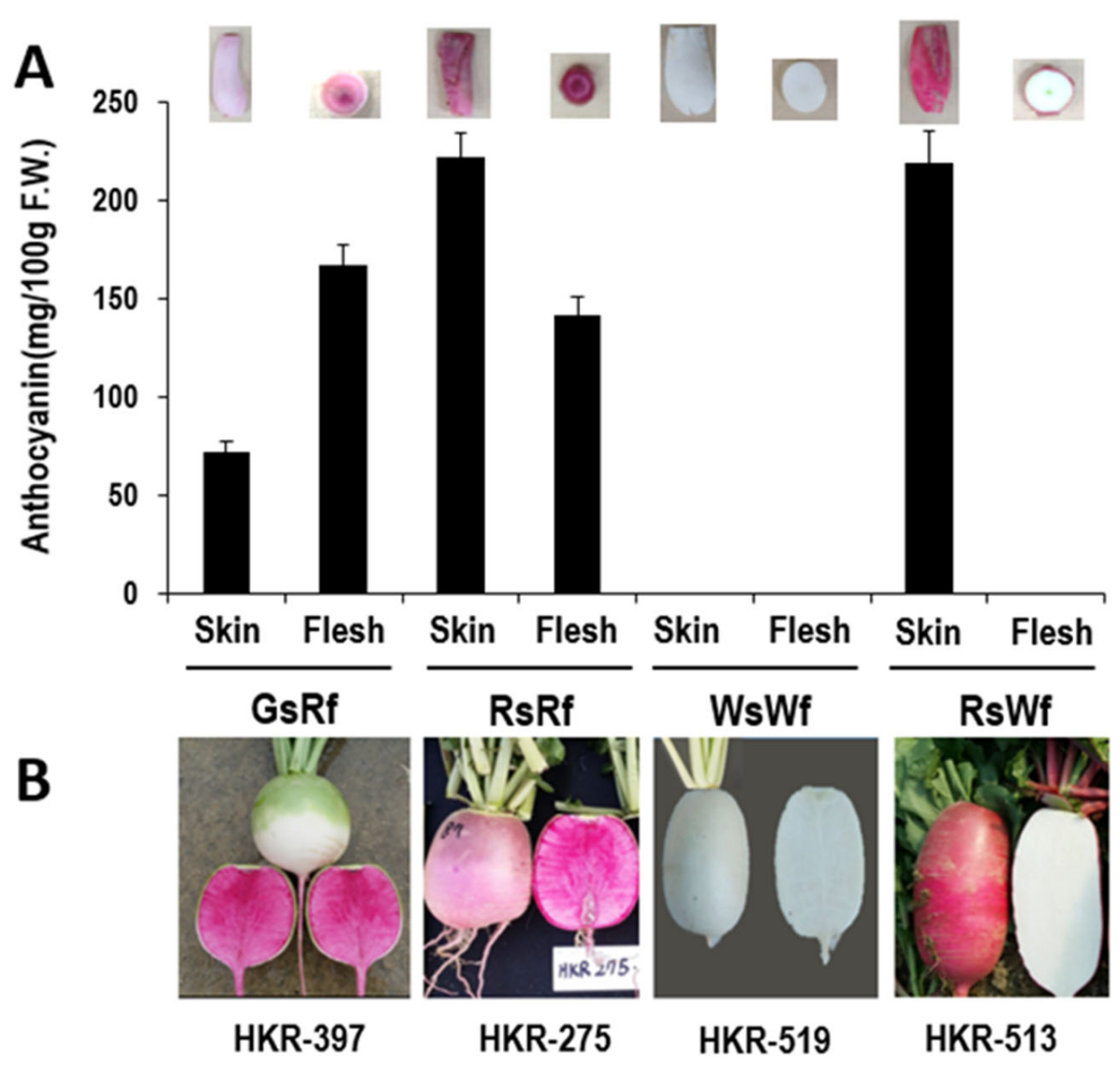

Figure 1. Four radish samples used in this study: green skin/red flesh (GsRf), red skin/red flesh (RsRf), white skin/white flesh (WsWf), and red skin/white flesh (RsWf) with inbred number (bottom). (A) Anthocyanin contents measured with 35-day-old samples. Real photos are on top. (B) Photographs taken at the harvest period.

\subsection{RsTT8 as a Target Gene for Affecting Anthocyanin Accumulation in Radish}

The presence of anthocyanin biosynthesis-related genes was determined by PCR (Figure 2A), and their expression in different organs or tissues was examined by semiquantitative RT-PCR (Figure 2B). Even though the transcript level of EBGs, such as RsCHS, $\mathrm{RsF} 3 \mathrm{H}$, and $\mathrm{RsF}^{\prime} \mathrm{H}$, was highly expressed in flesh tissue of Rf compared to Wf. The expression of target genes of the MBW complex formed by RsTT8 (RsMYB and RsTTG1), such as RsDFR and RsLDOX genes, was consistent with anthocyanin accumulation.

Expression levels of DFR, LDOX, and TT8 showed a strong correlation with anthocyanin accumulation in radishes. We selected the RsTT8 gene, which encodes an important component of the MBW complex, for further analysis as a putative regulator of anthocyanin accumulation in radish. 


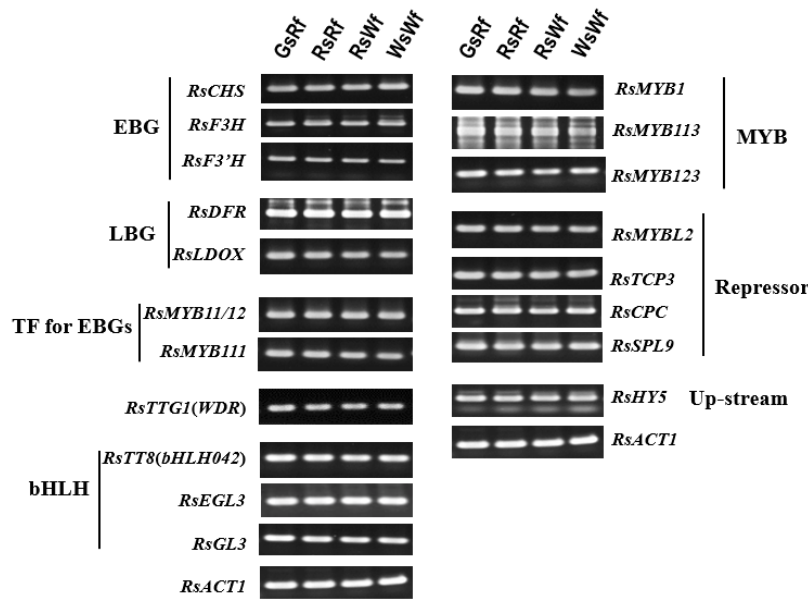

(A)

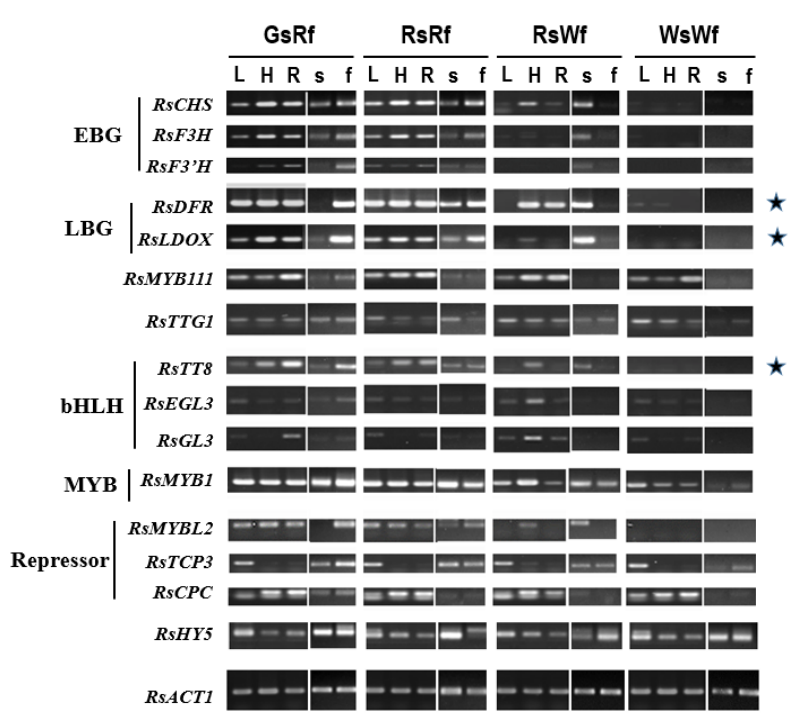

(B)

Figure 2. Presence (A) and expression (B) of genes related to anthocyanin accumulation in four radishes. (A) All genes were amplified by genomic DNA PCR. (B) Expression levels of genes. L, leaves, H, hypocotyls, R, roots, s, skin, and f, flesh. Asterisks indicated that expression levels were tightly related to anthocyanin accumulation.

\subsection{Cloning and Sequence Analysis of RsTT8}

The RsTT8 gene was isolated from all four radish inbred lines using gene-specific primers (Table S1), which were designed based on the sequence information available in various databases (see Materials and Methods). The sequence of at least 10 independent RsTT8 clones per genotype was analyzed to identify putative paralogs. Primer positions and RsTT8 gene structure are shown in Figure 3A. Nucleotide sequences of RsTT8 amplified from the different inbred lines and their alignment are shown in Figure S1. On the basis of sequence information, a schematic of the genomic structure of RsTT8 was redrawn to show several important residues or regions (Figure 3B). Several polymorphisms, such as SNPs, InDels, and SSRs, were identified between red-fleshed and white-fleshed radish lines (Figure S1, Table 1). An InDel immediately upstream of the transcription start site (TSS) and a dinucleotide (TC) SSR at the beginning of intron 2 were detected between red-fleshed and white-fleshed lines (Figure 3B). Phylogenetic analysis of RsTT8 nucleotide sequences clearly distinguished the red-fleshed lines from white-fleshed lines (Figure 4), suggesting that radish germplasm used in this study are inbred lines (not doubled haploid lines), and RsTT8-Wf alleles are distinct from RsTT8-Rf alleles. However, polypeptides encoded by RsTT8 genes amplified from all four inbred lines were well conserved (Figure 5), suggesting that the different anthocyanin accumulation levels among the four inbred lines are caused by differences in RsTT8 expression levels. 


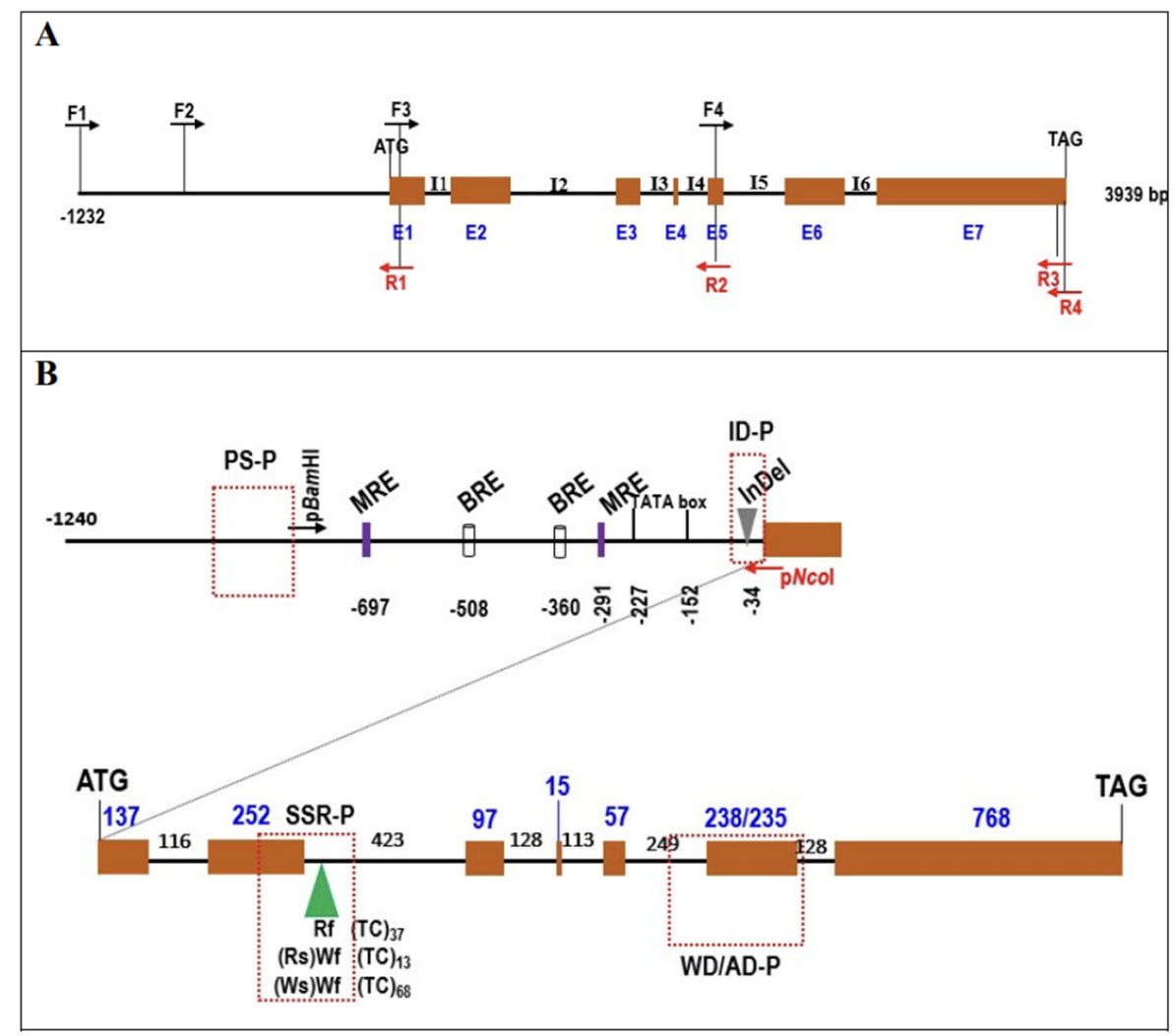

Figure 3. Schematic representation of genomic DNA of RsTT8 genes with primer position for cloning (A) and genomic organization of cloned RsTT8 genes (B). (A) Exon and intron are represented by box and solid line, respectively. I and E indicate intron and exon, respectively. Arrows indicated primer position and direction with forward (F) and reverse (R). (B) Genomic organization of cloned RsTT8 genes with promoter regions and 7 exons (box) and 6 introns (solid line). Numbers indicated nucleotide sequence (bp), and InDel and SSR regions were also marked. MRE, MYB-recognition motif; BRE. bHLH-recognition motif. Arrows named $\mathrm{pBamHI}$ and $\mathrm{pNcoI}$ indicated primers for promoter::GUS construction. Four boxes of dotted red lines indicate regions used in marker validation: PS-P, region amplified by promoter-specific primer set (-979 -818) (Rf-P/Wf-P in Table S1); ID$\mathrm{P}$, region amplified by $14 \mathrm{bp}$ InDel-discriminating primer set; SSR-P, region amplified by TC SSR including primer set; WD/AD-P, region amplified by primer set that discriminated one CAT InDel and three SNPs (Rf/Wf-P in Table S1).

Table 1. List of polymorphisms found in RsTT8 genes.

\begin{tabular}{cccccccccc}
\hline \multirow{2}{*}{ Region } & \multicolumn{3}{c}{ Between Rf and Wf } & \multicolumn{3}{c}{ WsWf-Specific } & \multicolumn{2}{c}{ RsWf-Specific } \\
\cline { 2 - 9 } & SNP & InDel & SSR & SNP & InDel & SSR & SNP & InDel & SSR \\
\hline Promoter & 16 & 2 & 1 & 2 & 4 & 1 & 2 & - & - \\
Exon & 2 & - & - & 1 & - & - & 3 & - & - \\
Intron & 10 & 1 & 2 & 3 & 3 & 2 & 3 & 9 & 1 \\
\hline Total & 28 & 3 & 3 & 6 & 7 & 3 & 1 \\
\hline
\end{tabular}




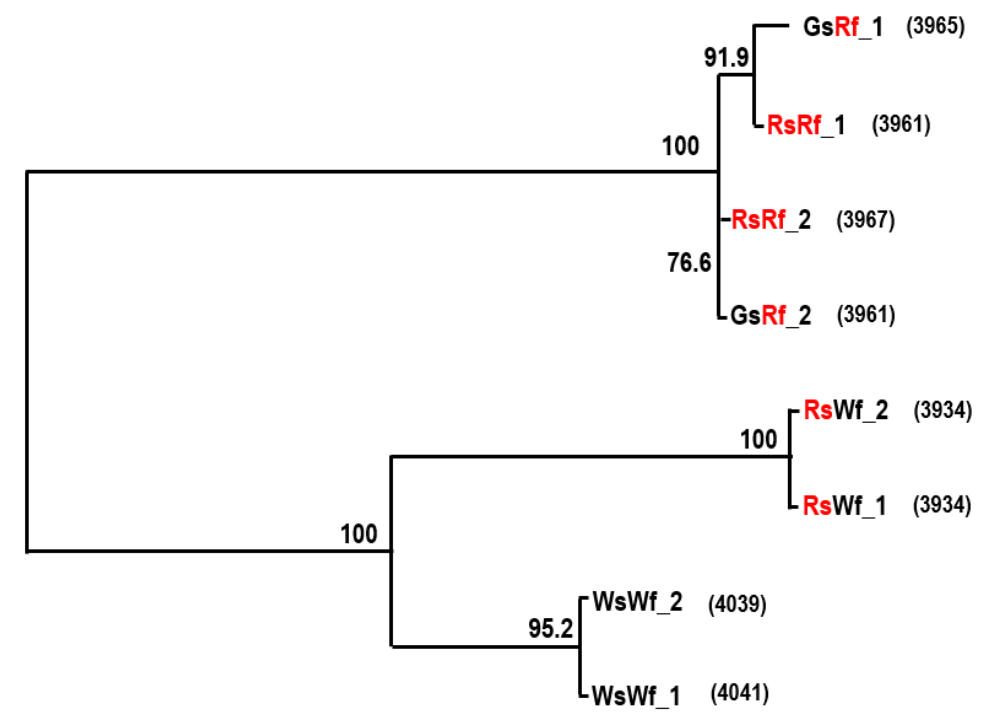

Figure 4. Phylogenetic relationship among RsTT8 alleles. Numbers in parenthesis indicate nucleotides of each allele.
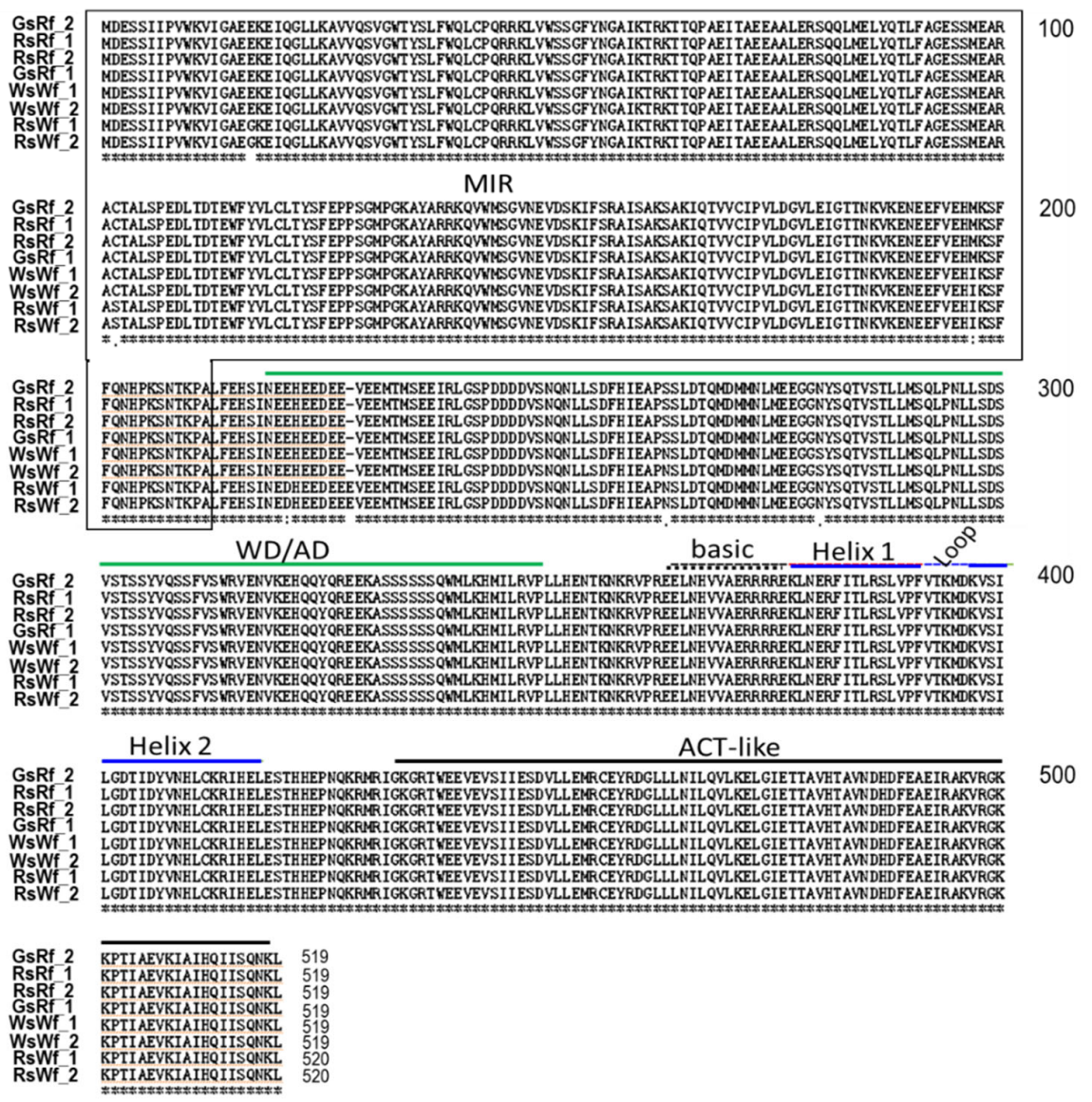

Figure 5. Alignment of amino acids of RsTT8 from four radishes used in this study. MIR (MYBinteracting domain), WD/AD (WDR interacting region through the acidic domain), bHLH region, and ACT-like domain were well conserved among RsTT8s, indicating that resulting proteins keep their activity. Regulation may depend on the expression level. Numbers on the right denoted the number of amino acid residues. 


\subsection{Promoter Analysis of RsTT8}

Regardless of the taproot color, all four radish inbred lines contained the RsTT8 gene (Figure 2A). However, the expression of RsTT8 was not detected in white tissues (Figure 2B). Although well-known cis-acting elements were conserved in RsTT8 genes of all four inbred lines, various polymorphisms were detected in the promoter regions, which led us to speculate that promoter activity of RsTT8 differs between red-fleshed and white-fleshed genotypes. However, the inbred lines showed no differences in RsTT8 promoter activity (Figure 6), suggesting that radish taproot flesh color is determined by RsTT8 expression level, which is regulated by an unknown upstream factor(s).

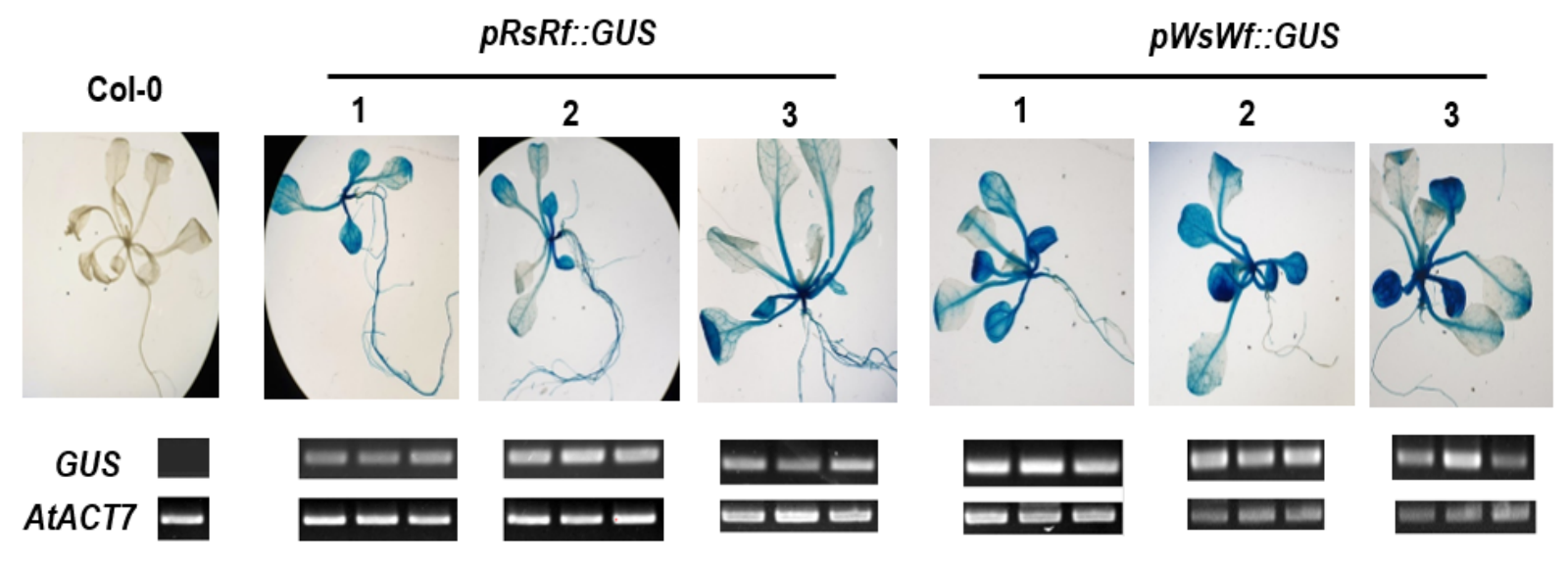

Figure 6. Promoter activity assay by GUS stain and RT-PCR.

\subsection{Development of Molecular Markers Associated with Flesh Color}

Red-fleshed and white-fleshed accessions could be distinguished based on sequence polymorphisms in RsTT8 (Figure 4). To develop molecular markers capable of distinguishing between red-fleshed and white-fleshed lines, we designed four PCR primer sets specific to different regions of the RsTT8 gene: (1) InDel, present immediately upstream of the TSS; (2) dinucleotide (TC) SSR, present at the beginning of the 1st intron; (3) coding sequence (CDS), forward primer was designed using the InDel present in intron 5 , and the reverse primer was designed using SNPs in exon 6; and (4) promoter, forward and reverse primers were designed using SNPs present between -979 and $-818 \mathrm{bp}$ (relative to the TSS). These four primer sets were tested on four inbred lines, three breeding materials, and four cultivars of radish (Figure 7). All four primer sets efficiently discriminated between red-fleshed and white-fleshed accessions. Radish cultivars RedSun, Rupr, and Anthopol, appeared to be heterozygous. 

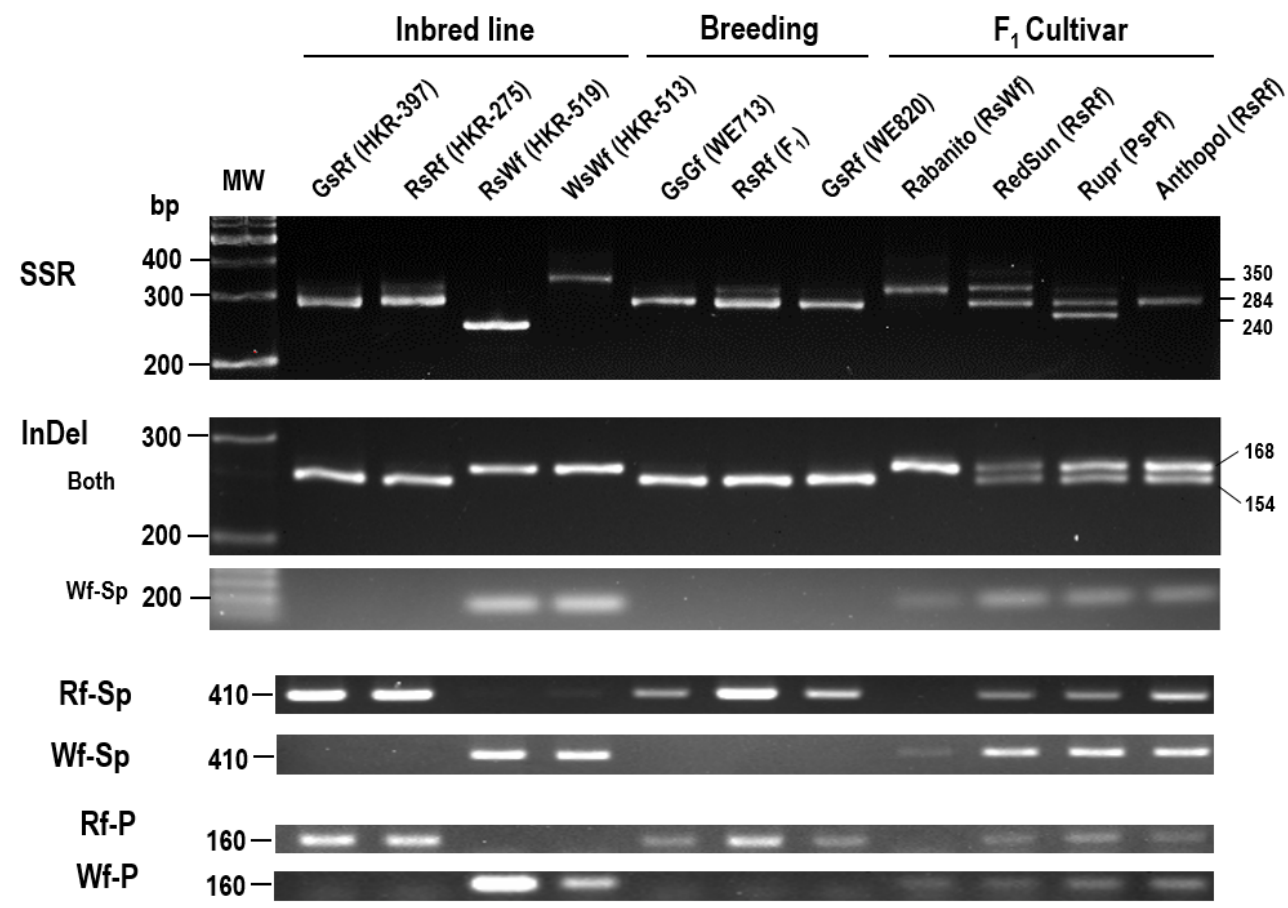

Figure 7. Development of PCR-markers derived from polymorphisms (SSR, InDel, and SNPs). (TC)SSRs were present in the 2nd intron ranging from (TC $)_{13}$ to $(\mathrm{TC})_{68}$. InDel was 14 nucleotide insertion in Wf gene and present at the 35th nucleotide of ATG upstream. Rf-Sp and Wf-Sp indicated that Rf-specific and Wf-specific amplification, respectively, which was designed using CAT InDel in 5th intron and SNP in exon 6. Rf-P/Wf-P indicated SNPs presented in the promoter regions between -979 to -818 nucleotide from ATG start codon. Primer sequences were listed in Table S1. Numbers on the right denoted size of band (bp).

To further test the utility of these primer sets, they were used for genotyping 14 radish accessions obtained from Hankook Seed Co. and one radish accession purchased from a local market (Figure 8). All primer sets accurately identified most red-fleshed inbred and recombinant lines, although R-346 (RsRf) seemed to be heterozygous. Two white-fleshed radish accessions contained RsTT8-Wf alleles. However, Chengwoo, a white-fleshed accession, contained Rf-type SSR. We also applied the markers to newly-developed inbred lines (Figure 9). Eight red-fleshed inbred lines showed a perfect correlation between genotype and phenotype, but two inbred lines, which were still segregating flesh color into Green or Red, appeared to be 'white flesh.' When we examined three more individuals, one of the 2225 lines turned out 'red flesh.' These data indicate that red-fleshed lines could be identified from a collection of radish genotypes, and escaping from segregation of green/red flesh color would be very difficult.

Since the SSR marker genotype did not match the phenotype in a few samples (Figures 7 and 8), we examined the SSR regions in 19 radish genotypes obtained from the NAC using the SSR-specific primer set. Sequence analysis revealed tremendous variation in the number of TC repeats between the red- and white-fleshed accessions and also among the white-fleshed genotypes (Table S2). This result suggests that the SSR marker is not suitable for distinguishing radish lines with different colored flesh. Thus, InDels and SNPs identified in the RSTT8 gene are ideal for the development of molecular markers for determining flesh coloration. 


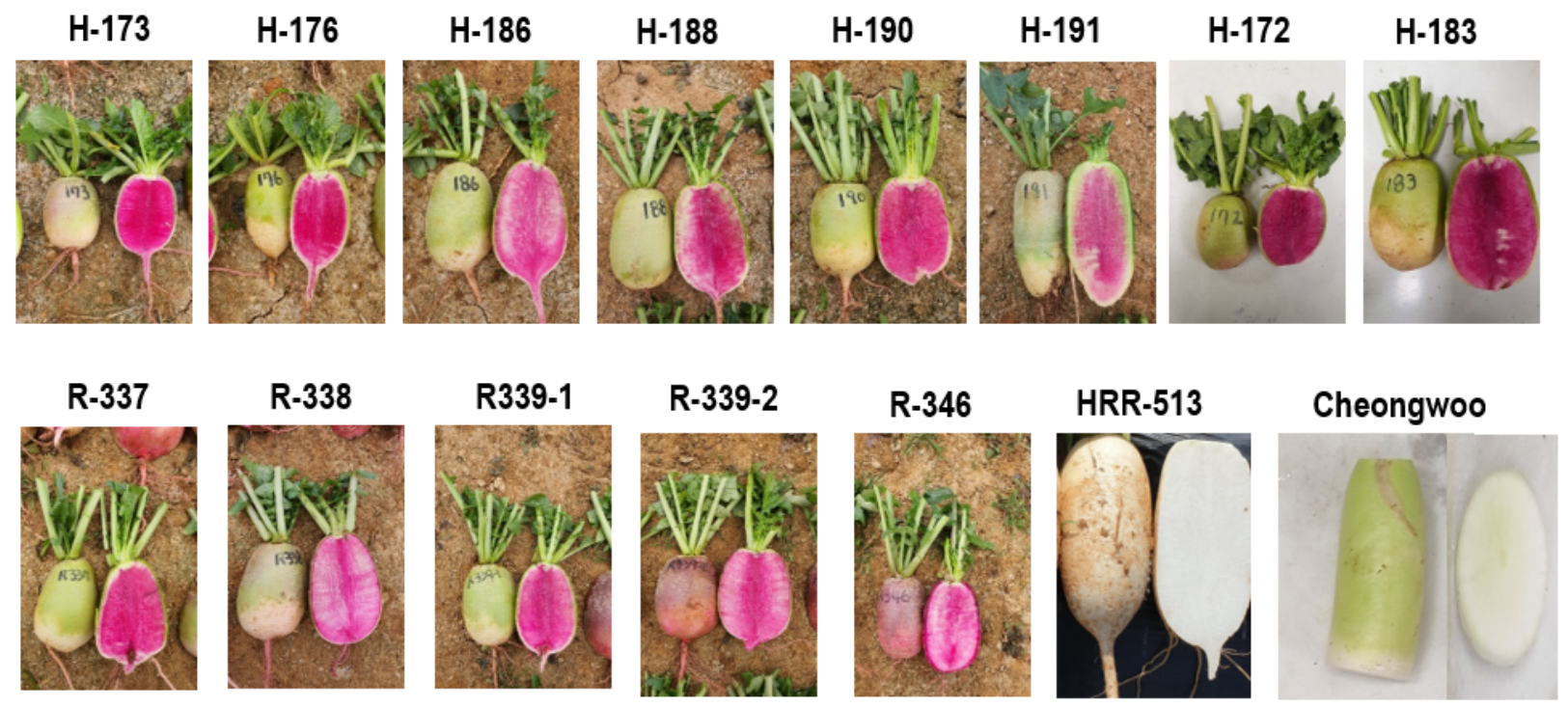

(A)

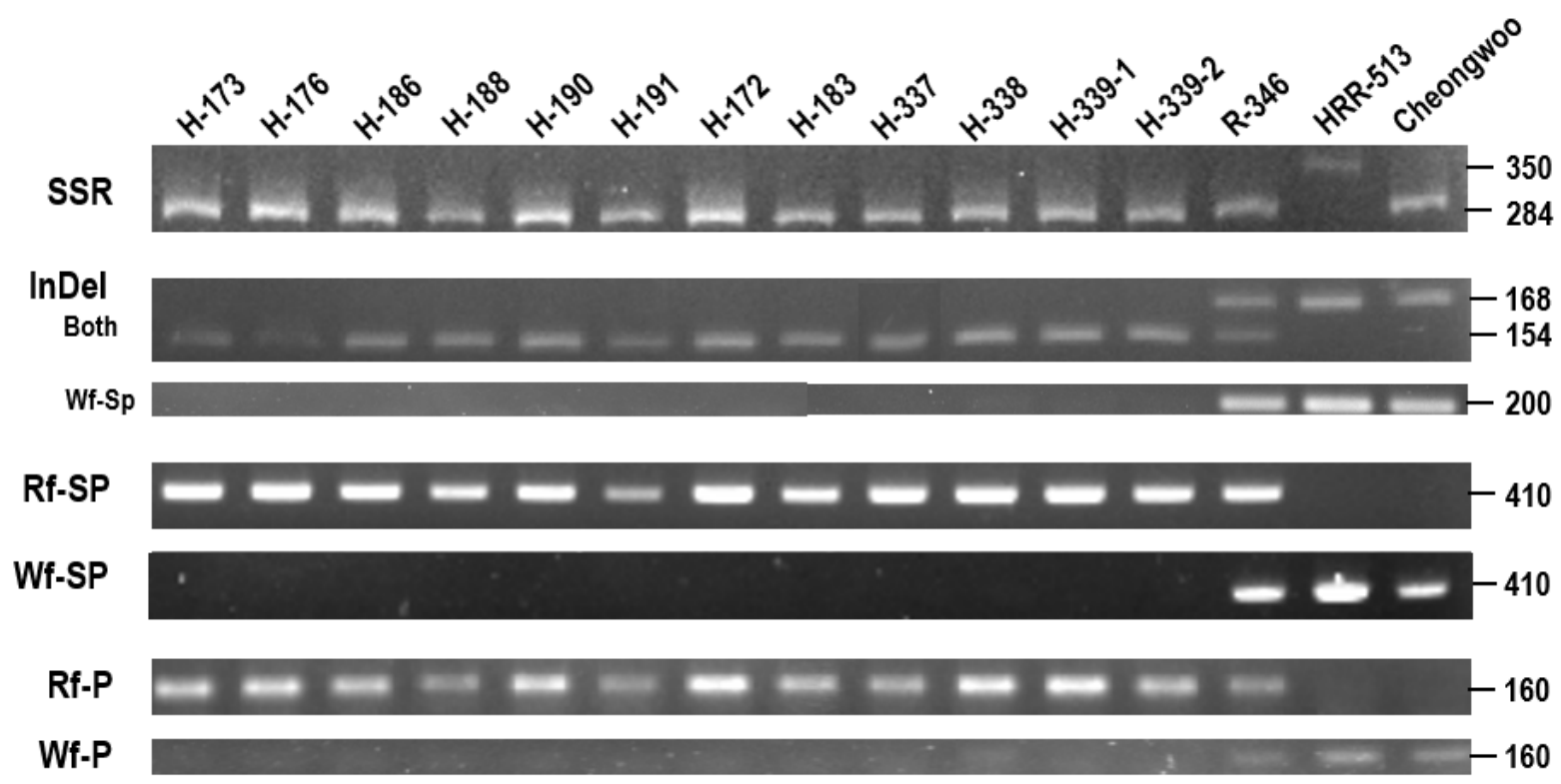

(B)

Figure 8. Validation of PCR-markers using $F_{1}$ cultivars in Korea. H and R indicate inbred and recombinant lines, respectively, from Hankook Seed Co. Numbers on the right, denote size of band (bp). (A) Morphology of taproots used in this study. (B) Results of PCR amplification. 


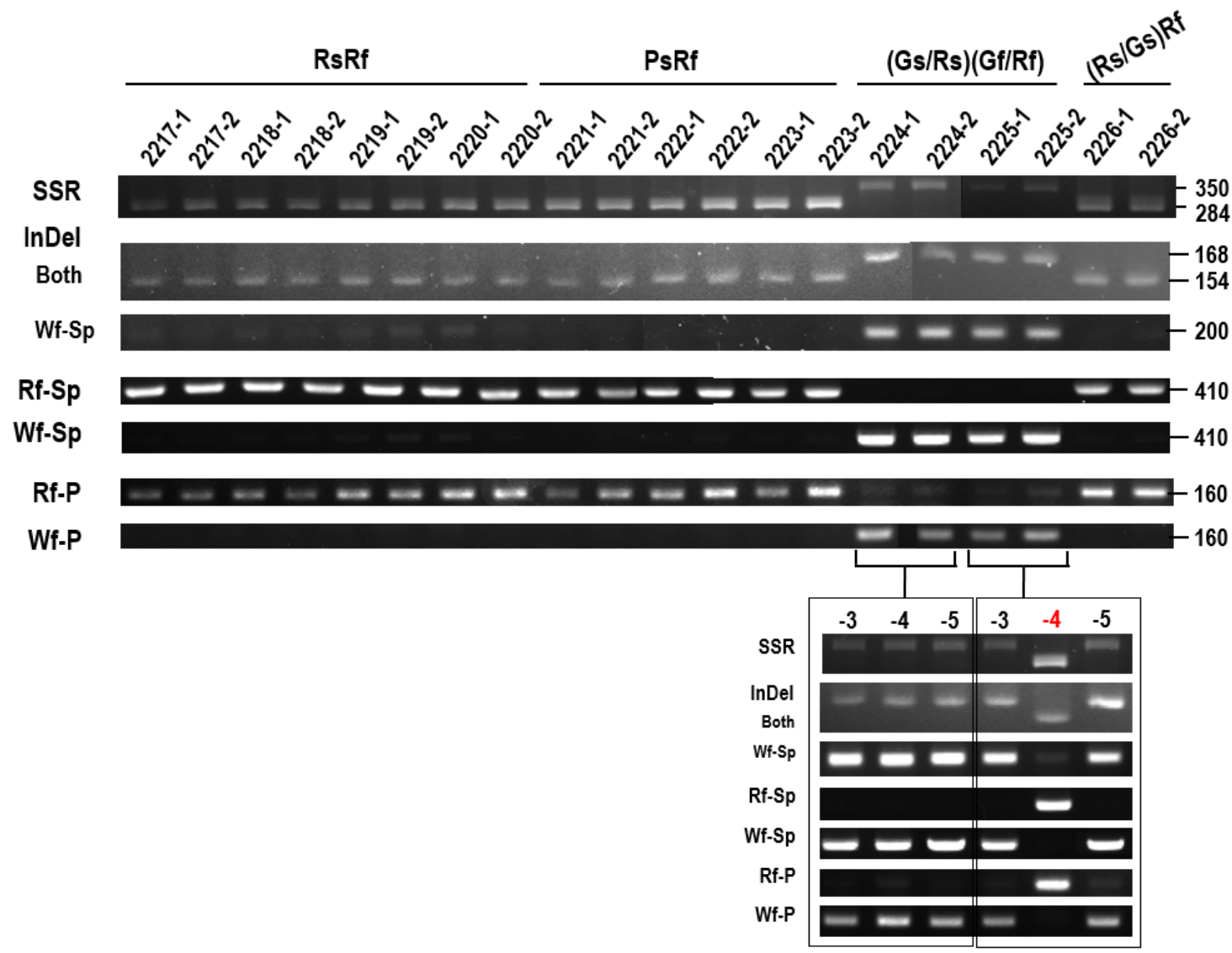

Figure 9. Validation of PCR-markers using newly developing radish lines in Sejong University. -P indicates the pink color and that lines were still segregated in terms of taproot color. Numbers on the right denoted size of band (bp). 2219 and 2221, $\mathrm{F}_{4}$ generation; 2220, $\mathrm{F}_{5}$ generation; 2217 and 2218, $\mathrm{F}_{6}$ generation; 2223-2226, $\mathrm{F}_{10}$ generation; 2222, $\mathrm{F}_{11}$ generation.

\section{Discussion and Conclusions}

Recently, several research groups performed transcriptomic analysis to identify the genes controlling anthocyanin accumulation in radish [3,33,37-44] and found that major genes and their regulatory transcription factors involved in the flavonoid biosynthetic pathway are essential for anthocyanin accumulation. However, none of these genes represents a novel regulatory gene that controls anthocyanin biosynthesis in a spatiotemporal or tissue-specific manner.

A few studies have investigated the role of RsTT8 in anthocyanin biosynthesis in radishes. The altered expression of TT8 due to TE insertion or a mutation decreases anthocyanin accumulation in B. rapa [34] and B. juncea [35]. In B. juncea, an insertion of $1279 \mathrm{bp}$ in exon seven of the TT8 gene disrupts its function, and the presence of a $\mathrm{C} \rightarrow \mathrm{T}$ SNP in exon seven results in the production of a truncated protein. On the other hand, upregulation of RsTT8 is associated with red skin or red flesh color in radish [33,37]. Similar to the results of the current study, four SNPs found in the first three exons of BoTT8 are associated with green or purple color in broccoli (B. oleracea var. italica L.) [36]. However, the presence of polymorphisms in RsTT8 and their association with radish taproot coloration have not been reported to date.

In this study, we identified a large number of polymorphisms in the RsTT8 gene isolated from red-fleshed and white-fleshed radish inbred lines and showed that some of these polymorphisms are associated with flesh color (Table 1, Figures 3 and 5). Regardless of the flesh color, all radish genotypes contained the RsTT8 gene (Figure 2A). Moreover, no TE insertion was found in RsTT8 in any of the four inbred lines, suggesting that RsTT8 was functional in all four lines. However, RsTT8 did not express in tissues 
lacking anthocyanin accumulation, such as radish lines with white flesh or white skin color (Figure 2B), and the expression of RsTT8 was not dependent on polymorphisms in the promoter (Figures 3 and 6). Despite the importance of TT8 in the regulation of anthocyanin biosynthesis, the mechanism underlying its regulation has not been identified yet. Nonetheless, the transcript level of RsTT8 is correlated with those of RsDFR and RsLDOX (Figure 2B), indicating the expression of RsTT8 is associated with that of two major LBGs.

Limited information is available on the genetics of flesh color in radish. Karyotype analysis suggests that the genetics underlying red flesh coloration in radish has evolved recently [45]. Several breeders speculate that anthocyanin accumulation is controlled in a recessive manner in radish (data not published). Epigenetic modifications of the genes encoding regulators of anthocyanin biosynthesis have been closely linked to color changes in crops, including radish. Changing the DNA methylation status of these regulatory genes affects the activities of the anthocyanin biosynthetic pathway. For example, methylation of the PcMYB10 promoter in European pear (Pyrus communis) is associated with greenskinned spots in a red pear cultivar [46]. However, Wang et al. (2020) insist that radish flesh color is under epigenetic control; the authors propose that white-fleshed radish originated from a red-fleshed accession following the hypermethylation of RsMYB1 by a CACTA transposon, resulting in considerable downregulation of RsMYB1 expression [47]. However, the above type of repression did not occur (Figure 2B) in the radish accessions used in this study, indicating that epigenetic modifications are not an absolute determinant of flesh color. However, the $F_{10}$ inbred lines 2224 and 2225 (Figure 9) should be examined to determine whether the epigenetic regulation of RsMYB1 affects flesh color in radish to confirm regulation of anthocyanin biosynthesis in terms of epigenetic control with further study.

Marker development and application are very important for breeding radish cultivars because the selection of genotypes for taproot coloration is impossible at the seedling stage. The outer layer of the hypocotyl in radish does not reflect anthocyanin accumulation in mature tissues because this layer peels off before maturation. The skin color of a mature taproot is therefore different from that of a young seedling. This is quite different from Brassica seedlings, in which the seedling stage is adequate for the selection of anthocyaninaccumulating genotypes. Therefore, DNA-based molecular markers are highly valuable for radish breeding.

\section{Materials and Methods}

\subsection{Plant Materials}

Four radish inbred lines were used in this study: HKR-397 (GsRf), HKR-275 (RsRf), HKR-519 (WsWf), and HKR-513 (RsWf). Seeds of these inbred lines were kindly supplied by Hankool Seed Co. Ltd. (143-71 Yucheon-Ro, Pyeongtaek-si, Gyeongii-Do, Korea). Additional seeds or tissues used in this study were provided by Hankook Seed Co. or purchased from the local market. Inbred lines (2217 to 2226) used for marker development were bred from the 4 th to the 11th filial generation. Radish germplasm used for determining the number of SSRs was obtained from the National Agrobiodiversity Center (NAC), Jeonju 54874 , Republic of Korea.

Seeds were sown in pots with multiple perforations at the bottom. After germination, seedlings were transplanted into appropriate pots and grown in either an environmentally controlled growth chamber or in a glass greenhouse at Chungnam National University, Daejeon, Korea. Plants were photographed prior to sampling at four distinct stages (young seedling stage, before and after the peeling off of hypocotyl skin, and harvest stage). The sampled tissues were frozen until needed for DNA extraction.

\subsection{Genomic DNA Extraction and Cloning and Sequence Analysis of RsTT8}

Genomic DNA was isolated from the leaf tissues of all four radish inbred lines using the DNeasy Plant Mini Kit (QIAGEN, Hilden, Germany). To amplify the RsTT8 gene, primers were designed on the basis of sequence information available at the Na- 
tional Center for Biotechnology Information (NCBI) and two radish genome databases (http:/ / radish-genome.org/ and http:/ / www.nodai-genome-d.org/, accessed on 9 March 2019) (Table S1). PCR was performed under the following conditions: initial denaturation at $94{ }^{\circ} \mathrm{C}$ for $5 \mathrm{~min}$, followed by 30 cycles of amplification $\left(94^{\circ} \mathrm{C}\right.$ for $30 \mathrm{~s}, 58^{\circ} \mathrm{C}$ for $30 \mathrm{~s}$, and $72{ }^{\circ} \mathrm{C}$ for $2-5 \mathrm{~min}$ ), and a final extension at $72{ }^{\circ} \mathrm{C}$ for $7 \mathrm{~min}$. PCR products were purified using the LaboPass Gel Extraction Kit (Cosmogenetech, Seoul, Korea) and cloned into the TA vector using the T\&A Cloning Kit (RBC Bioscience Co., Taipei, Taiwan). The resulting plasmids were transformed into Escherichia coli (DH5 $\alpha$ ) cells. Plasmid DNA was purified using DNA-Spin (Intron Biotech. Inc., Seongnam, Korea), and sequenced. To obtain all possible RsTT8 sequences present in each inbred line, at least 10 clones of each line were sequenced and analyzed. Any possible PCR and/or sequencing errors were eliminated by aligning independent sequences. The RsTT8 gene sequences amplified from all four inbred lines were deposited in the NCBI GenBank database under the accession numbers: RsWf_TT8_1 (MW657230), RsWf_TT8_2 (MW657231), GsRf_TT8_1 (MW657232), GsRf_TT8_2 (MW657233), RsRf_TT8_1 (MW657234), RsRf_TT8_2 (MW657235), WsWf_TT8_1 (MW657236), and WsWf_TT8_2 (MW657237).

PCR was conducted to determine the presence or absence of genes in radish samples using $5 \mathrm{ng}$ of genomic DNA under the following conditions: initial denaturation at $94{ }^{\circ} \mathrm{C}$ for $5 \mathrm{~min}$, followed by 29 cycles of amplification $\left(94^{\circ} \mathrm{C}\right.$ for $30 \mathrm{~s}, 60^{\circ} \mathrm{C}$ for $30 \mathrm{~s}$, and $72{ }^{\circ} \mathrm{C}$ for $30 \mathrm{~s}$ ), and a final extension at $72{ }^{\circ} \mathrm{C}$ for $5 \mathrm{~min}$. The resulting PCR products were separated by electrophoresis on $1.5 \%$ agarose gel.

\subsection{RNA Extraction and Gene Expression Analysis}

Total RNA was extracted from plant samples using the RNeasy Mini Kit (Qiagen, Hilden, Germany) and then treated with RNase-free DNase (Promega, Madison, WI, USA) to remove genomic DNA contamination. Then, cDNA was synthesized by semiquantitative reverse transcription PCR (RT-PCR) using the Avian Myeloblastosis Virus (AMV) One-step RT-PCR Kit (Takara, Kyoto, Japan) and gene-specific primers (Tables S1 and S3) under the following conditions: initial denaturation at $94{ }^{\circ} \mathrm{C}$ for $5 \mathrm{~min}$, followed by 27 cycles of amplification $\left(94{ }^{\circ} \mathrm{C}\right.$ for $30 \mathrm{~s}, 60^{\circ} \mathrm{C}$ for $30 \mathrm{~s}$, and $72{ }^{\circ} \mathrm{C}$ for $30 \mathrm{~s}$ ), and a final extension at $72{ }^{\circ} \mathrm{C}$ for $7 \mathrm{~min}$. PCR products were separated on $1.5 \%$ agarose gels and stained with ethidium bromide.

\subsection{Anthocyanin Extraction and Quantification}

Anthocyanin content was measured as described previously [48]. Briefly, $1 \mathrm{~mL}$ of $1 \%(v / v) \mathrm{HCl}-m e t h a n o l$ was added to $0.3 \mathrm{~g}$ of the powdered leaf tissue. The sample was shaken gently in the dark at room temperature for $24 \mathrm{~h}$ and then centrifuged at $13,000 \times g$. The upper aqueous phase was collected, and its absorbance was measured at 530,620 , and $650 \mathrm{~nm}$. Relative anthocyanin content (RAC) was calculated according to the following equation:

$$
\mathrm{RAC}=\left(\mathrm{A}_{530}-\mathrm{A}_{620}\right)-0.1 \times\left(\mathrm{A}_{650}-\mathrm{A}_{620}\right)
$$

where $A_{530}, A_{620}$, and $A_{650}$ represent the absorbance of the aqueous layer at 530, 620, and $650 \mathrm{~nm}$, respectively.

Total anthocyanin content (TAC; mg anthocyanin/100 $\mathrm{g}$ fresh weight) was then calculated on the basis of the reference, cyanidin-3-glucoside [49], according to the following equation:

$$
\mathrm{TAC}=\mathrm{RAC} \times \mathrm{MW} \times \mathrm{DF} \times 1000 \times \ni
$$

where MW is the molecular weight of cyanidin-3-glucoside (449.2 g/mol), DF is the dilution factor and, $\ni$ is the cuvette optical path length $(1 \mathrm{~cm})$. 


\subsection{Promoter Activity Assay}

To analyze the RsTT8 promoter activity, the approximately 870-bp sequence upstream of the TSS of the RsTT8 gene was amplified from the genomic DNA of WsWf and RsRf inbred lines using sequence-specific primers (Table S1). The amplified fragments were inserted into the T\&A cloning vector (Real Biotech Co., Taipei, Taiwan), and the presence of the insert was confirmed by sequencing. The resulting recombinant plasmids were digested with $\mathrm{BamHI}$ and $\mathrm{NcoI}$, and the released fragments were subcloned into the pCambina3301-GUS binary vector digested with the same enzymes. The resulting constructs were introduced into Arabidopsis thaliana ecotype Columbia (Col-0; wild type) plants by Agrobacterium-mediated transformation using the floral dip method [50]. The transformed plants were selected using $0.1 \%$ Basta herbicide and confirmed by PCR. Homozygous $\mathrm{T}_{3}$ lines containing a single copy of the T-DNA, determined by 3:1 (Basta resistant: sensitive) segregation ratio, were selected for the analysis of promoter activity.

Wild-type and transgenic Arabidopsis plants were grown in a growth chamber at $22{ }^{\circ} \mathrm{C}$ under a 16-h light/8-h dark photoperiod and $100 \mu \mathrm{mol} \mathrm{m}^{-2} \mathrm{~s}^{-1}$ light intensity. To analyze RsTT8 promoter activity, wild-type and transgenic seeds were surface-sterilized with 30\% bleach containing $0.1 \%$ Triton X-100, cold-stratified at $4{ }^{\circ} \mathrm{C}$ for 3 days, and then sown on solid half-strength Murashige and Skoog (1/2 MS) medium supplemented with or without $90 \mathrm{mM}$ sucrose. Three plants of each genotype were sampled for analyzing GUS expression by RT-PCR, and another three plants per genotype were used to perform GUS staining. To perform GUS staining, plants were incubated in GUS-staining solution (1 mM X-GlucA in $100 \mathrm{mM}$ sodium phosphate [pH 7.0] containing $5 \mathrm{mM} \mathrm{Na}_{2}$ EDTA, $0.5 \mathrm{mM}$ potassium ferrocyanide, $0.5 \mathrm{mM}$ potassium ferricyanide, and $0.1 \%$ Triton $\mathrm{X}-100$ ) for $16 \mathrm{~h}$ at $37^{\circ} \mathrm{C}$. After staining, the plants were washed with $95 \%$ ethanol at room temperature until the wild-type plants appeared clear.

\subsection{Marker Development and Validation}

DNA was extracted from leaf samples of various radish genotypes using the DNeasy Plant Mini Kit (QIAGEN, Hilden, Germany). PCR was performed in a $20 \mu \mathrm{L}$ volume containing 5-20 ng genomic DNA template, 10 pmol each of forward and reverse InDel-, SNP-, or SSR-specific primers (Table S1), and $4 \mu \mathrm{L}$ of 5X PCR Master Mix (Elpisbiotech, Daejeon, Korea), under the following conditions: $94{ }^{\circ} \mathrm{C}$ for $5 \mathrm{~min}$, followed by 30 cycles at $94{ }^{\circ} \mathrm{C}$ for $30 \mathrm{~s}, 62{ }^{\circ} \mathrm{C}$ for $30 \mathrm{~s}$, and $72{ }^{\circ} \mathrm{C}$ for $30 \mathrm{~s}$, with a final extension at $72{ }^{\circ} \mathrm{C}$ for $5 \mathrm{~min}$. To verify the presence of genomic DNA, B. oleracea Actin 1 (BoActin1) was simultaneously amplified. The PCR products were separated by electrophoresis on $1 \%$ agarose gels. Additionally, DNA sequences flanking the InDels and SSRs were amplified by PCR under the same conditions as those used for marker validation (Table S1). The PCR products were sequenced, and their association with radish flesh coloration was examined.

Supplementary Materials: The following are available online at https:/ / www.mdpi.com/article/10 .3390 / plants10071386/s1, Figure S1: Nucleotide sequence of the RsTT8 gene isolated from four radish inbred lines, Table S1: Primer sequence information used in this study, Table S2: Number of TC-SSR in various radishes obtained from National Agrobiodiversity Center (NAC), Jeonju 54874, Republic of Korea, Table S3: Primer sequences used in genomic DNA PCR and qRT-PCR in Brassica spp. and Raphanus sativus.

Author Contributions: Y.H., H.Y.P. and M.-H.O. conceived the study; S.K., K.Y., J.Y.A., J.Y.Y., H.S. and O.N.L. performed the experiments and developed the methodology and laboratory analyses; Y.H. and M.-H.O. wrote and reviewed the manuscript. All authors read and approved the final version of the manuscript.

Funding: This work was supported in part by a grant from the Basic Science Research Program through the National Research Foundation of Korea (NRF) funded by the Ministry of Education (NRF-2017R1D1A3B0303375314), Republic of Korea, and this work was carried out with the support of "Cooperative Research Program for Agriculture Science and Technology Development (Project No. PJ01481605)" Rural Development Administration, Republic of Korea. 
Institutional Review Board Statement: Not applicable.

Informed Consent Statement: Not applicable.

Data Availability Statement: Not applicable.

Conflicts of Interest: The authors declare no conflict of interest.

\section{References}

1. Park, C.H.; Baskar, T.B.; Park, S.-Y.; Kim, S.-J.; Valan Arasu, M.; Al-Dhabi, N.A.; Kim, J.K.; Park, S.U. Metabolic profiling and antioxidant assay of metabolites from three radish cultivars (Raphanus sativus). Molecules 2016, 21, 157. [CrossRef]

2. Chen, F.; Xing, C.; Huo, S.; Cao, C.; Yao, Q.; Fang, P. Red pigment content and expression of genes related to anthocyanin biosynthesis in radishes (Raphanus sativus L.) with different colored flesh. J. Agric. Sci. 2016, 8, 10.5539. [CrossRef]

3. Sun, Y.; Wang, J.; Qiu, Y.; Liu, T.; Song, J.; Li, X. Identification of 'Xinlimei'radish candidate genes associated with anthocyanin biosynthesis based on a transcriptome analysis. Gene 2018, 657, 81-91. [CrossRef] [PubMed]

4. Muminović, J.; Merz, A.; Melchinger, A.E.; Lubberstedt, T. Genetic structure and diversity among radish varieties as inferred from AFLP and ISSR analyses. J. Am. Soc. Hortic. Sci. 2005, 130, 79-87. [CrossRef]

5. Hanlon, P.R.; Barnes, D.M. Phytochemical composition and biological activity of 8 varieties of radish (Raphanus sativus L.) sprouts and mature taproots. J. Food Sci. 2011, 76, C185-C192. [CrossRef] [PubMed]

6. Giusti, M.M.; Wrolstad, R.E. Radish anthocyanin extract as a natural red colorant for maraschino cherries. J. Food Sci. 1996, 61, 688-694. [CrossRef]

7. Giusti, M.M.; Rodriguex-Saona, L.E.; Baggett, J.R.; Reer, G.L.; Durst, R.W.; WRolstad, R.E. Anthocyanin pigment composition of red radish cultivars as potential food colorants. J. Food Sci. 1998, 63, 219-224. [CrossRef]

8. Giusti, M.M.; Ghanadan, H.; Wrolstad, R.E. Elucidation of the structure and conformation of red radish (Raphanus sativus) anthocyanins using one-and two-dimensional nuclear magnetic resonance techniques. J. Agric. Food Chem. 1998, 46, 4858-4863. [CrossRef]

9. Gutiérrez, R.M.P.; Perez, R.L. Raphanus sativus (Radish): Their chemistry and biology. Sci. World J. 2004, 4, 811-837. [CrossRef]

10. $\mathrm{Wu}, \mathrm{X}$; Prior, R.L. Identification and characterization of anthocyanins by high-performance liquid chromatography- electrospray ionization - tandem mass spectrometry in common foods in the United States: Vegetables, nuts, and grains. J. Agric. Food Chem. 2005, 53, 3101-3113. [CrossRef]

11. Park, N.I.; Xu, H.; Li, X.; Jang, I.H.; Park, S.; Ahn, G.H.; Lim, Y.P.; Kim, S.J.; Park, S.U. Anthocyanin accumulation and expression of anthocyanin biosynthetic genes in radish (Raphanus sativus). J. Agric. Food Chem. 2011, 59, 6034-6039. [CrossRef]

12. Lepiniec, L.; Debeaujon, I.; Routaboul, J.-M.; Baudry, A.; Pourcel, L.; Nesi, N.; Caboche, M. Genetics and biochemistry of seed flavonoids. Annu. Rev. Plant Biol. 2006, 57, 405-430. [CrossRef]

13. Dubos, C.; Le Gourrierec, J.; Baudry, A.; Huep, G.; Lanet, E.; Debeaujon, I.; Routaboul, J.M.; Alboresi, A.; Weisshaar, B.; Lepiniec, L. MYBL2 is a new regulator of flavonoid biosynthesis in Arabidopsis thaliana. Plant J. 2008, 55, 940-953. [CrossRef] [PubMed]

14. Zimmermann, I.M.; Heim, M.A.; Weisshaar, B.; Uhrig, J.F. Comprehensive identification of Arabidopsis thaliana MYB transcription factors interacting with R/B-like BHLH proteins. Plant J. 2004, 40, 22-34. [CrossRef]

15. Mehrtens, F.; Kranz, H.; Bednarek, P.; Weisshaar, B. The Arabidopsis transcription factor MYB12 is a flavonol-specific regulator of phenylpropanoid biosynthesis. Plant Physiol. 2005, 138, 1083-1096. [CrossRef] [PubMed]

16. Stracke, R.; Ishihara, H.; Huep, G.; Barsch, A.; Mehrtens, F.; Niehaus, K.; Weisshaar, B. Differential regulation of closely related R2R3-MYB transcription factors controls flavonol accumulation in different parts of the Arabidopsis thaliana seedling. Plant J. 2007, 50, 660-677. [CrossRef] [PubMed]

17. Li, S. Transcriptional control of flavonoid biosynthesis: Fine-tuning of the MYB-bHLH-WD40 (MBW) complex. Plant Signal. Behav. 2014, 9, e27522. [CrossRef]

18. Debeaujon, I.; Nesi, N.; Perez, P.; Devic, M.; Grandjean, O.; Caboche, M.; Lepiniec, L. Proanthocyanidin-accumulating cells in Arabidopsis testa: Regulation of differentiation and role in seed development. Plant Cell 2003, 15, 2514-2531. [CrossRef] [PubMed]

19. Baudry, A.; Heim, M.A.; Dubreucq, B.; Caboche, M.; Weisshaar, B.; Lepiniec, L. TT2, TT8, and TTG1 synergistically specify the expression of BANYULS and proanthocyanidin biosynthesis in Arabidopsis thaliana. Plant J. 2004, 39, 366-380. [CrossRef]

20. Pires, N.; Dolan, L. Origin and diversification of basic-helix-loop-helix proteins in plants. Mol. Biol. Evol. 2010, $27,862-874$. [CrossRef]

21. Heim, M.A.; Jakoby, M.; Werber, M.; Martin, C.; Weisshaar, B.; Bailey, P.C. The basic helix-loop-helix transcription factor family in plants: A genome-wide study of protein structure and functional diversity. Mol. Biol. Evol. 2003, 20, 735-747. [CrossRef]

22. Feller, A.; Hernandez, J.M.; Grotewold, E. An ACT-like domain participates in the dimerization of several plant basic-helix-loophelix transcription factors. J. Biol. Chem. 2006, 281, 28964-28974. [CrossRef]

23. Hülskamp, M.; Miséra, S.; Jürgens, G. Genetic dissection of trichome cell development in Arabidopsis. Cell 1994, 76, 555-566. [CrossRef]

24. Bernhardt, C.; Lee, M.M.; Gonzalez, A.; Zhang, F.; Lloyd, A.; Schiefelbein, J. The bHLH genes GLABRA3 (GL3) andENHANCER OF GLABRA3 (EGL3) specify epidermal cell fate in the Arabidopsis root. Development 2003, 130, 6431-6439. [CrossRef] 
25. Zhang, F.; Gonzalez, A.; Zhao, M.; Payne, C.T.; Lloyd, A. A network of redundant bHLH proteins functions in all TTG1-dependent pathways of Arabidopsis. Development 2003, 130, 4859-4869. [CrossRef] [PubMed]

26. Gonzalez, A.; Zhao, M.; Leavitt, J.M.; Lloyd, A.M. Regulation of the anthocyanin biosynthetic pathway by the TTG1/bHLH/Myb transcriptional complex in Arabidopsis seedlings. Plant J. 2008, 53, 814-827. [CrossRef]

27. Feyissa, D.N.; Løvdal, T.; Olsen, K.M.; Slimestad, R.; Lillo, C. The endogenous GL3, but not EGL3, gene is necessary for anthocyanin accumulation as induced by nitrogen depletion in Arabidopsis rosette stage leaves. Planta 2009, 230, 747-754. [CrossRef] [PubMed]

28. Li, P.; Chen, B.; Zhang, G.; Chen, L.; Dong, Q.; Wen, J.; Mysore, K.S.; Zhao, J. Regulation of anthocyanin and proanthocyanidin biosynthesis by M edicago truncatula b HLH transcription factor M t TT 8. New Phytol. 2016, 210, 905-921. [CrossRef]

29. Symonds, V.V.; Hatlestad, G.; Lloyd, A.M. Natural allelic variation defines a role for ATMYC1: Trichome cell fate determination. PLoS Genet. 2011, 7, e1002069. [CrossRef]

30. Bruex, A.; Kainkaryam, R.M.; Wieckowski, Y.; Kang, Y.H.; Bernhardt, C.; Xia, Y.; Zheng, X.; Wang, J.Y.; Lee, M.M.; Benfey, P. A gene regulatory network for root epidermis cell differentiation in Arabidopsis. PLoS Genet. 2012, 8, e1002446. [CrossRef] [PubMed]

31. Nesi, N.; Debeaujon, I.; Jond, C.; Pelletier, G.; Caboche, M.; Lepiniec, L. The TT8 gene encodes a basic helix-loop-helix domain protein required for expression of DFR and BAN genes in Arabidopsis siliques. Plant Cell 2000, 12, 1863-1878. [CrossRef] [PubMed]

32. Baudry, A.; Caboche, M.; Lepiniec, L. TT8 controls its own expression in a feedback regulation involving TTG1 and homologous MYB and bHLH factors, allowing a strong and cell-specific accumulation of flavonoids in Arabidopsis thaliana. Plant J. 2006, 46, 768-779. [CrossRef]

33. Lim, S.-H.; Kim, D.-H.; Kim, J.K.; Lee, J.-Y.; Ha, S.-H. A radish basic helix-loop-helix transcription factor, RsTT8 acts a positive regulator for anthocyanin biosynthesis. Front. Plant Sci. 2017, 8, 1917. [CrossRef]

34. Li, X.; Chen, L.; Hong, M.; Zhang, Y.; Zu, F.; Wen, J.; Yi, B.; Ma, C.; Shen, J.; Tu, J. A large insertion in bHLH transcription factor BrTT8 resulting in yellow seed coat in Brassica rapa. PLoS ONE 2012, 7, e44145. [CrossRef] [PubMed]

35. Padmaja, L.K.; Agarwal, P.; Gupta, V.; Mukhopadhyay, A.; Sodhi, Y.S.; Pental, D.; Pradhan, A.K. Natural mutations in two homoeologous TT8 genes control yellow seed coat trait in allotetraploid Brassica juncea (AABB). Theor. Appl. Genet. 2014, 127, 339-347. [CrossRef]

36. Rahim, M.A.; Resentini, F.; Dalla Vecchia, F.; Trainotti, L. Effects on plant growth and reproduction of a peach R2R3-MYB transcription factor overexpressed in tobacco. Front. Plant Sci. 2019, 10, 1143. [CrossRef] [PubMed]

37. Yu, R.; Du, X.; Li, J.; Liu, L.; Hu, C.; Yan, X.; Xia, Y.; Xu, H. Identification and differential expression analysis of anthocyanin biosynthetic genes in root-skin color variants of radish (Raphanus sativus L.). Genes Genom. 2020, 42, 413-424. [CrossRef] [PubMed]

38. Muleke, E.; Fan, L.; Wang, Y.; Xu, L.; Zhu, X.; Zhang, W.; Cao, Y.; Karanja, B.K.; Liu, L. Coordinated regulation of anthocyanin biosynthesis genes confers varied phenotypic and spatial-temporal anthocyanin accumulation in radish (Raphanus sativus L.). Front. Plant Sci. 2017, 8, 1243. [CrossRef]

39. Zhang, X.; Su, N.; Jia, L.; Tian, J.; Li, H.; Huang, L.; Shen, Z.; Cui, J. Transcriptome analysis of radish sprouts hypocotyls reveals the regulatory role of hydrogen-rich water in anthocyanin biosynthesis under UV-A. BMC Plant Biol. 2018, 18, 1-14. [CrossRef] [PubMed]

40. Gao, J.; Li, W.-B.; Liu, H.-F.; Chen, F.-B. De novo transcriptome sequencing of radish (Raphanus sativus L.) fleshy roots: Analysis of major genes involved in the anthocyanin synthesis pathway. BMC Mol. Cell Biol. 2019, 20, 1-12. [CrossRef] [PubMed]

41. Gao, J.; Peng, H.; Chen, F.; Luo, M.; Li, W. Genome-wide analysis of transcription factors related to anthocyanin biosynthesis in carmine radish (Raphanus sativus L.) fleshy roots. PeerJ 2019, 7, e8041. [CrossRef]

42. Liu, T.; Wang, J.; Wu, C.; Zhang, Y.; Zhang, X.; Li, X.; Wang, H.; Song, J.; Li, X. Combined QTL-Seq and traditional linkage analysis to identify candidate genes for purple skin of radish fleshy taproots. Front. Genet. 2019, 10, 808. [CrossRef] [PubMed]

43. Liu, T.; Zhang, Y.; Zhang, X.; Sun, Y.; Wang, H.; Song, J.; Li, X. Transcriptome analyses reveal key genes involved in skin color changes of 'Xinlimei'radish taproot. Plant Physiol. Biochem. 2019, 139, 528-539. [CrossRef]

44. Fan, L.; Xu, L.; Wang, Y.; Tang, M.; Liu, L. Genome-and Transcriptome-wide characterization of bZIP gene family identifies potential members involved in abiotic stress response and anthocyanin biosynthesis in radish (Raphanus sativus L.). Int. J. Mol. Sci. 2019, 20, 6334. [CrossRef]

45. Xu, J.; Xu, D.; Yao, Q.; Chen, F. Karyotype analysis of radish (Raphanus sativus L.) with different freshy colors. J. Henan Agric. Sci. 2011, 40, 120-125.

46. Wang, Z.; Meng, D.; Wang, A.; Li, T.; Jiang, S.; Cong, P.; Li, T. The Methylation of the PcMYB10 Promoter Is Associated with Green-Skinned Sport in Max Red Bartlett Pear. Plant Physiol. 2013, 162, 885-896. [CrossRef] [PubMed]

47. Wang, Q.; Wang, Y.; Sun, H.; Sun, L.; Zhang, L. Transposon-induced methylation of the RsMYB1 promoter disturbs anthocyanin accumulation in red-fleshed radish. J. Exp. Bot. 2020, 71, 2537-2550. [CrossRef]

48. Lee, H.; Wicker, L. Anthocyanin pigments in the skin of lychee fruit. J. Food Sci. 1991, 56, 466-468. [CrossRef]

49. Giusti, M.M.; Wrolstad, R.E. Characterization and measurement of anthocyanins by UV-visible spectroscopy. Curr. Protoc. Food Anal. Chem. 2001, F1.2.1-F1.2.13. [CrossRef]

50. Clough, S.J.; Bent, A.F. Floral dip: A simplified method for Agrobacterium-mediated transformation of Arabidopsis thaliana. Plant J. 1998, 16, 735-743. [CrossRef] 